\title{
Two more HIV protease inhibitors approved
}

With its deliberative sessions fluctuating between the exuberance of a sporting event and the tedium of a jury trial, an advisory panel recommended to the US Food and Drug Administration (FDA, Rockville, MD) that it approve two new drugs-both HIV protease inhibitors-for treating AIDS. In less than 24 hours, agency officials, led by regulatory reform-inspired commissioner David Kessler, moved at extraordinary speed to approve Abbott's (Abbott Park, IL) ritonavir. Ten days later, the agency similarly expedited approval of Merck's (Whitehouse Station, NJ) indinavir, delayed only because of the company's need to prepare for the product launch.

These drugs join the Hoffmann-La Roche (Nutley, NJ) product, saquinavir, approved late in 1995 (Bio/Technology 14:23, 1996). By several in vitro measures, the two more recently reviewed drugs are particularly potent against HIV. And, in the short term at least, that potency translates into reduced virus levels in the blood, higher immune system activity, and possibly extended life and other clinical benefits for AIDS patients.

To say that approval for these drugs came easily or that their availability will turn the tide against HIV risks oversimplifying a still complex set of developments and challenges involving AIDS research. Indeed, the high cost of the new protease inhibitors, which in most cases will need to be taken together with one or even several other antiviral drugs, is already stirring resentment among AIDS activists who contend that few individuals can afford long-term use of these products. Recognizing the health care implications of this drug-cost problem, President Clinton announced in tandem with FDA's ritonavir approval decision that he will seek an additional $\$ 52$ million from the US Congress to support the federal AIDS drug assistance project.

Although approval of the Merck and Abbott drugs was virtually a foregone conclusion, the advisory panel review in early March did not go as smoothly as many observers had anticipated, for the Abbott's ritonavir (Norvir). Part of the problem is that Abbott provided the agency, not only with surrogate marker data to track disease in HIV-infected patients, but also with clinical end-point data from a trial involving latestage AIDS patients. Perversely, this seemingly sound clinical research strategy nearly backfired.

In clinical trials, Abbott's ritonavir or a placebo was administered with nucleoside analogue inhibitors of HIV to patients with advanced AIDS. Despite some unpleasant gastrointestinal side effects, some peripheral nerve disorders, and interaction with many other drugs, the clinical progress and the delay in death among the treatment group were significantly better than among patients in the control group.

For instance, $34 \%$ of the placebo group patients experienced an AIDS-defining clinical event, compared to $17 \%$ in the ritonavir group; moreover $10 \%$ of the placebo group died, compared to $5.7 \%$ among the ritonavir patients. Other data from these and from less severely $\mathrm{HIV}$-infected individuals indicate that ritonavir also reduces virus levels about 100 -fold and increases $\mathrm{CD}^{+} \mathrm{T}$-cell levels in planned to obtain the needed data. Ultimately, some adroit maneuvering by FDA officials and a pledge from Abbott to design and quickly begin the requisite studies led the panel to recommend the drug. On the very next day, the agency approved it.

FDA granted ritonavir "accelerated approval" for use in patients with less advanced HIV disease, but "full approval" for use alone or with nucleoside analogues in individuals with advanced disease. "The review of ritonavir is the . . shortest drug approval in modern history, 72 days," David Kessler says with obvious enthusiasm. "We worked late into the night for Abbott."

The Abbott maneuverings overshadowed the review and subsequent approval of Merck's drug, indinavir (Crixivan), which

\begin{tabular}{|c|c|c|}
\hline roduct & Company & Clinical status \\
\hline $\begin{array}{l}\text { Reverse transcriptas } \\
\text { Viramune } \\
\text { Delavirdine mesylate } \\
\text { HIVID (R) } \\
\text { GS } 840 \\
\text { AZT } \\
\text { BTC }\end{array}$ & $\begin{array}{l}\text { Boehringer Ingelheim (Ingelheim, Germany) } \\
\text { Pharmacia/Upjohn (Kalamazoo, MI) } \\
\text { Hoffmann-La Roche (Basel, Switzerland) } \\
\text { Gilead Sciences (Foster City, CA) } \\
\text { Glaxo-Wellcome (London, UK) } \\
\text { Biochem Pharma (Quebec, Canada) }\end{array}$ & $\begin{array}{l}\text { Phase III } \\
\text { Phase III } \\
\text { Approved } \\
\text { Phase I/II complete } \\
\text { Approved } \\
\text { Approved }\end{array}$ \\
\hline $\begin{array}{l}\text { Protease inhibitors } \\
\text { VIRACEPT } \\
\text { Ritonavir } \\
\text { Crixivan } \\
\text { Invirase } \\
\text { KVX-478 }\end{array}$ & $\begin{array}{l}\text { Agouron Pharmaceuticals (La Jolla, CA) } \\
\text { Abbott Laboratories (Abbott Park, IL) } \\
\text { Merck (Whitehouse Station, NJ) } \\
\text { Hoffman-La Roche (Nutley, NJ) } \\
\text { Vertex (Cambridge, MA) }\end{array}$ & $\begin{array}{l}\text { Phase II/III combination } \\
\text { Approved March } 1996 \\
\text { Approved March } 1996 \\
\text { Approved February } 1996 \\
\text { Phase II; oral phase I }\end{array}$ \\
\hline $\begin{array}{l}\text { Integrase inhibitors } \\
\text { AR177 }\end{array}$ & Aronex Pharmaceuticals (The Woodlands, TX) & Phase I \\
\hline
\end{tabular}

the blood of patients - two common indices associated with antiviral drug efficacy.

Such clear-cut efficacy findings are ordinarily welcome. However, because of a quirk in FDA regulations, Abbott's positive but somewhat limited clinical end-point results momentarily threatened the recommendation for ritonavir approval. The FDA rules specify that the agency may rely on surrogate marker findings when considering products for "accelerated approval," but that clinical end-point results must be used for "full approval." The usual tradeoff is that, to receive market licenses into accelerated approval with its relaxed standards, companies must begin-and promise to complete-follow-up clinical end-point studies.

In ritonavir's case, advisory panel members liked the efficacy findings for patients with advanced AIDS but were caught offguard-as was the company, it seemsbecause there were no comparable findings for less severely affected individuals. Abbott had no trials under way, nor had they won undiluted praise and an unequivocal recommendation for accelerated approval. Ironically, Merck provided the panel with little beyond surrogate marker clinical data. But that evidence for indinavir's efficacy, which comes from several clinical trials, proved very convincing to agency officials and advisory panel members. For instance, a broad range of HIV-infected individuals who received indinavir (with other antiviral drugs) showed more than 100-fold decreases in blood levels of HIV and substantial CD4 $T$-cell level increases - sustained for 48 weeks or more-compared to a control group.

Moreover, indinavir has been well tolerated and produced few, relatively mild, side effects (except for a few cases of kidney stones because of its low solubility) among the more than 2000 individuals treated with it so far. It shows little sign of causing serious interactions with other drugs. And Merck plans to price it at $30 \%$ below Abbott's Norvir.

Jeffrey L. Fox 